\title{
The Comparison of Environmental Impacts of Carbonized Briquettes from Rain Tree Residues and Coffee Grounds/Tea Waste and Traditional Waste Management
}

\author{
Chaisuwan N., Kansai N., Supakata N., and Papong S.
}

\begin{abstract}
The objective of this research was to investigate and compare the cradle-to-grave environmental impacts of five ratios of carbonized briquettes obtained from rain tree (Samanea saman) residues and coffee grounds/tea waste and traditional waste management including landfill disposal and composting. The SimaPro 8.0.5.13 software was used for life cycle assessment analysis. The results were grouped into six impact categories: acidification, eutrophication, global warming, ozone layer depletion, human toxicity and photochemical oxidation. The results showed that carbonization and briquetting processes were the main source of global warming, ozone layer depletion and photochemical oxidation due to the pollutants emitted from an electric briquetting machine and the diesel fuel used for carbonization. Composting rain tree residues had the lowest impact on global warming at $0.02 \%$. Conversely, the carbonized briquette obtained from coffee grounds/tea waste had the highest impact on global warming at $21.57 \%$. This impact resulted from the high amount of electricity used for briquetting and the diesel fuel used for carbonization. On the other hand, composting rain tree residues had the highest impact on acidification and eutrophication with $90.01 \%$ and $82.85 \%$, respectively, due to utilization of the compost for soil amendment. Thus, carbonized briquettes from rain tree residues and coffee grounds/tea waste were an alternative way to reduce waste to landfill and to add value to biomass residues for use as raw materials for producing fuel products.
\end{abstract}

Index Terms - Life cycle assessment, carbonized briquette, rain tree, coffee ground/tea waste.

\section{INTRODUCTION}

Biomass briquettes, made mostly from green waste and other organic materials, are commonly used for cooking and in boilers. The briquette technology is the process of compacting loose biomass to form a compacted and shaped product. According to the Thai Community Product Standard (TCPS), briquettes' characteristics consist of the heating value $(>5000 \mathrm{kcal} / \mathrm{kg})$, the moisture content $(<8 \%)$ and the

Manuscript received May 20, 2019; revised November 2, 2019. This project was supported by the Department of Environmental Science, Faculty of Science, Chulalongkorn University and was partially supported by the Research Program: Municipal Solid Waste and Hazardous Waste Management, Center of Excellence on Hazardous Substance Management (HSM-PJ-CT-17-02).

Chaisuwan N. and Kansai N. were with the Department of Environmental Science, Faculty of Science, Chulalongkorn University, Bangkok, Thailand (e-mail: nichakorn.c@hotmail.com,yung_ZzAa@hotmail.com).

Supakata N. is with the Department of Environmental Science, Faculty of Science, Chulalongkorn University, Bangkok, Thailand (corresponding author; e-mail: nuta.s@chula.ac.th).

Papong S. is with the National Metal and Materials Technology Center, Pathum Thani, Thailand (e-mail: seksanp@mtec.or.th). lack of smoke and scent when ignited by fire [1]. One of the most common variables of the briquette process is the way in which volatile compounds and moisture are dried out of the organic matter called carbonization, the most efficient forms of drying out biomass with a higher proportion of carbon [2] If this is the case, the carbonization process is applied to increase the fixed carbon and to remove the moisture content and volatile matter from the briquettes [3].

Rain tree residues and coffee grounds/tea waste can be used as raw materials to produce the carbonized briquettes. When cassava starch is used as a binder, the briquettes are a good tool for household cooking because of their transportation convenience and environmental friendliness [4]. The method for carbonized briquettes production can be divided into two steps: the carbonization and the briquetting that improves the fixed carbon content [5].

However, the carbonization process can release carbon dioxide ) $\mathrm{CO}_{2}$ (, nitrous oxide ) $\mathrm{N}_{2} \mathrm{O}$ (and methane ) $\mathrm{CH}_{4}$ ( [6]. Many tools have analyzed the environmental impacts of different processes [7]. To evaluate the environmental performance of the carbonized briquettes from rain tree residues and coffee grounds/tea waste, the Life Cycle Assessment (LCA) is often used as a comprehensive tool to evaluate the environmental impact of such products or services. The scope of this assessment is the entire life cycle of a product, from the extraction of raw materials to the manufacturing, use and end of life [8]. According to the ISO 14040, the LCA has four steps, including goal and scope, inventory analysis, impact assessment, and interpretation [9]. LCA is used to identify environmental impacts [10] and provide analysis for integrated waste management [11].

Hu et al. [12] published an environmental assessment of briquette fuel from agricultural residues using the LCA method. This assessment covered the entire life cycle, from raw material acquisition to disposal (also known as cradle-to-grave). According to this assessment, briquettes from corn stalks had a high environmental impact due to electricity consumption during the briquetting process.

Rousset et al. [13] investigated the LCA of charcoal briquettes using the $\mathrm{GaBi} 4.3$ database software and the Global Warming Potential (100 years). The study included every stage of the production (cradle-to-grave). According to the study, charcoal briquettes from eucalyptus had the most impact due to $\mathrm{CO}_{2}$ emissions released during the briquetting process.

However, carbonized briquettes from rain tree residues and coffee grounds/tea waste can be an alternative way to add value to residues [4]. No studies have examined the Life Cycle Assessment (LCA) in the field of carbonized briquettes 
from rain tree residues and coffee grounds/tea waste.

The purpose of this study was to compare the LCA of the carbonized briquettes produced from rain tree residues and coffee grounds/tea waste with the traditional waste management of these residues. Traditional waste management techniques are associated with environmental impacts such as acidification, eutrophication, global warming, ozone layer depletion, human toxicity and photochemical oxidation. The life cycle stages began with raw materials acquisition and ended with disposal, either of the carbonized briquette or the traditional disposal of biomass. This inclusion of all life cycle stages is called "cradle-to-grave."

\section{METHODS}

\section{A. Methods of the LCA of Briquettes}

\section{1) Goal and scope}

As stated above, the goal of this study was to investigate and compare the environmental life cycle impact of carbonized briquettes made from rain tree residues and coffee grounds/tea waste residues and traditional waste management including landfill disposal and composting. Carbonized briquettes made from rain tree residues and coffee grounds/tea waste were mixed into five ratios including RT100:CT0, RT75:CT25, RT50:CT50, RT25:CT75 and RT0:CT100. These ratios were studied to discover the optimal ratio with the lowest environmental impact. The analysis used in this study followed the cradle-to-grave phases of the LCA (Fig. 1 and Fig. 2). The functional unit was defined as one piece of carbonized briquette (150 g/unit).

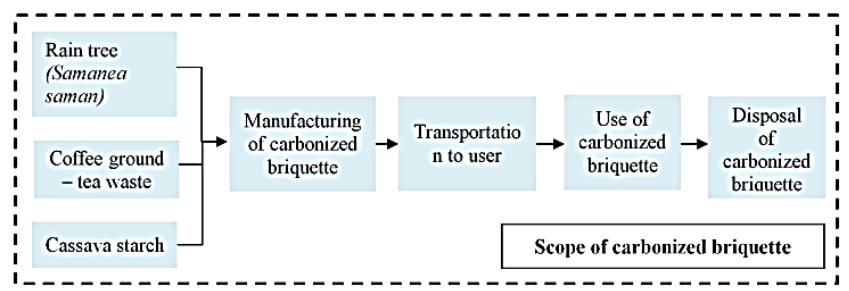

Fig. 1. The system boundaries of study include raw material acquisition to disposal of carbonized briquettes.

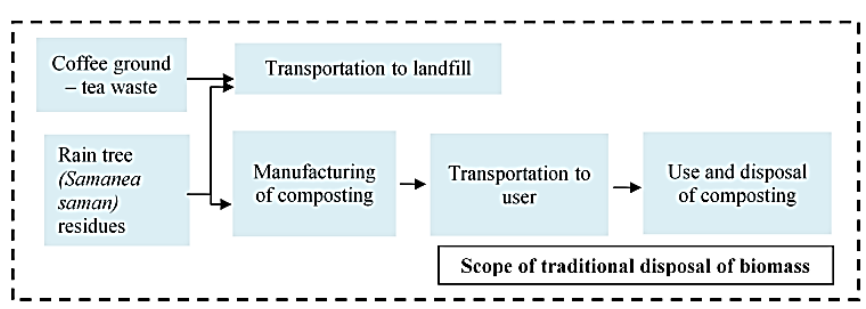

Fig. 2. The system boundaries of the study include raw material acquisition to traditional disposal of biomass.

\section{B. Assumptions}

1) Vehicles used for LCA calculation in this study were trucks with four wheels and a max payload of seven tons. Diesel was used as fuel.

2) The distance used for the LCA calculation in this study (transportation for carbonized briquettes and compost) was $10 \mathrm{~km}$ (from Chulalongkorn University to the consumer).

3) The distance used for the LCA calculation in this study (transportation to landfill) was $45 \mathrm{~km}$ (from Chulalongkorn University to the landfill at Nongkhaem).

4) The raw materials used in the carbonized briquette process were assumed to be residues at Chulalongkorn University that did not cause environmental impact.

5) Carbonized briquettes and composting were assumed to be products from Chulalongkorn University that did not cause environmental impact. Thus, environmental impact was calculated only from transportation of the product.

6) The raw materials in traditional waste management such as transportation to the landfill were assumed to be residues at Chulalongkorn University which did not cause environmental impact. Thus, environmental impact was calculated only from raw material transportation.

\section{Life Cycle Inventory}

\section{1) Data preparation}

Rain tree residues were collected from Chulalongkorn University, Bangkok. Coffee grounds/tea waste was obtained from a coffee shop in Chulalongkorn University, Bangkok. Cassava starch was purchased from a bakery shop.

\section{2) Inventory and data calculation}

The life cycle inventory (LCI) showed the material and energy flows (input and output) at every stage of the life cycle from raw materials acquisition to disposal (Rousset et al., 2011). This process was divided into two parts: (1) the LCA of raw materials acquisition to the disposal of carbonized briquettes and (2) the LCA of traditional waste management by landfill disposal.

There were five processes for carbonized briquettes: diesel production, carbonized briquetting, the transportation, utilization and landfill disposal (Fig. 3).

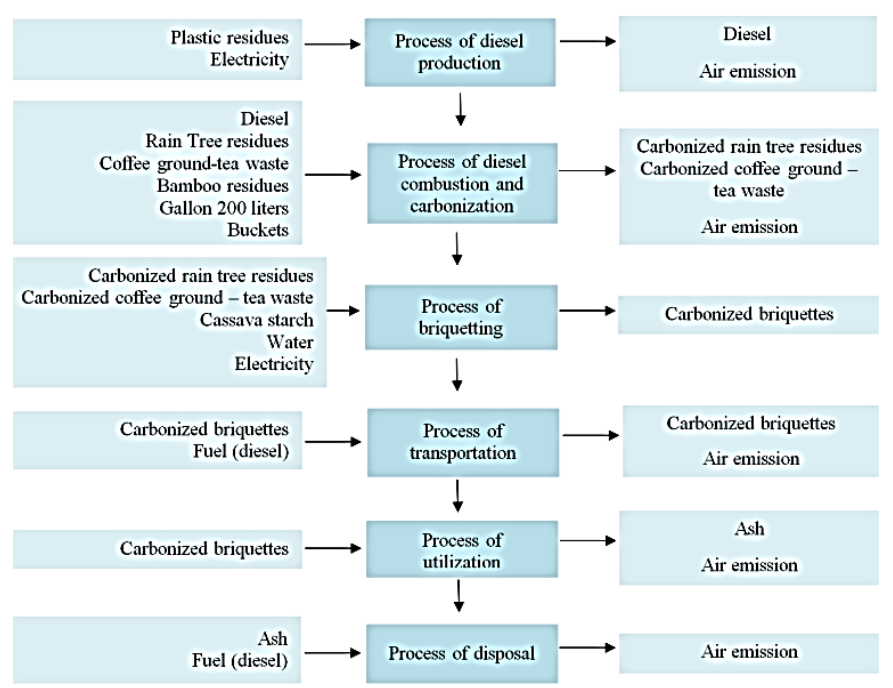

Fig. 3. Life Cycle Inventory (LCI) of carbonized.

There were three steps in traditional waste management through composting: composting, transportation and utilization and disposal (Fig. 4).

There were two steps in traditional waste management by landfill disposal: transportation and landfill disposal (Fig. 5). 


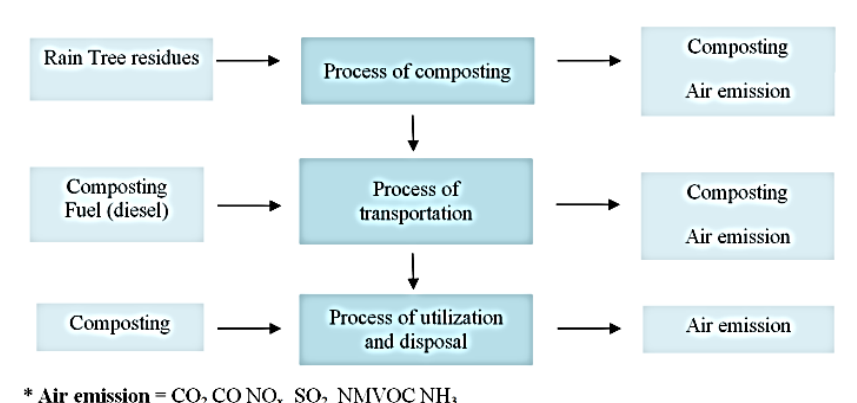

Fig. 4. LCI of traditional waste management by composting.

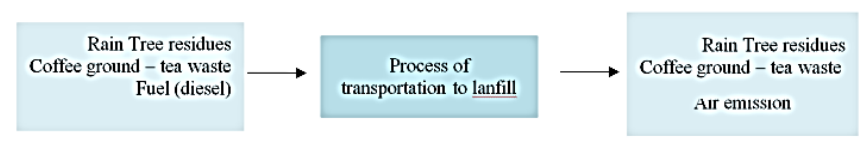

* Air emission $=\mathrm{CO}_{2} \mathrm{CONO} \mathrm{SO}_{2} \mathrm{NMVOC} \mathrm{NH}_{3} \mathrm{CH}_{4}$

Fig. 5. LCI of traditional waste management by the disposal of biomass in a landfill.

\section{Life Cycle Impact Assessment (LCIA)}

\section{1) Classification}

The air emission estimation methodology covered exhaust emissions by diesel production, diesel combustion, carbonization, briquetting, transportation, utilization and disposal. These were further categorized into global warming $\left(\mathrm{CO}_{2}\right)$, ozone layer depletion (CO, $\left.\mathrm{NO}_{\mathrm{x}}, \mathrm{NMVOC}\right)$, acidification $\left(\mathrm{NO}_{\mathrm{x}}, \mathrm{SO}_{2}, \mathrm{NH}_{3}\right)$, eutrophication $\left(\mathrm{NO}_{\mathrm{x}}, \mathrm{NH}_{3}\right)$, human toxicity $\left(\mathrm{SO}_{2}, \mathrm{NO}_{\mathrm{x}}, \mathrm{CO}\right.$, Benzo [a] pyrene, Benzo [k] fluoranthene, Benzo [b] floranthene) and photochemical oxidation (NMVOC). These were estimated using the IPCC 2007 guidelines [14] and EEA 2016 air emission inventory guidebook [15].

\section{2) Data calculation and characteristics}

Calculation of environmental impact potential used the following equations (1):

\section{Emission of exhaust pollutants}

$$
\text { Emission }=\sum[\text { Fuel } \mathrm{XF}]
$$

where:

Emission $=$ emission in $\mathrm{kg}$

Fuel $=$ fuel consumed $(\mathrm{TJ})$

$\mathrm{EF}=$ emission factor $(\mathrm{kg} / \mathrm{TJ})$

The life cycle assessment study was carried out using the SimaPro 8.0.5.13 software from National Metal and Materials Technology Center (MTEC). Results were expressed in six categories of impact, including global warming, ozone layer depletion, acidification, eutrophication, human toxicity and photochemical oxidation.

\section{Interpretation}

In this step, the data were analyzed. The results from the SimaPro 8.0.5.13 software calculation were collected to show the environmental impacts of carbonized briquettes, landfill disposal and composting.

\section{RESUlTS AND DisCUSSION}

The LCA was carried out with the SimaPro 8.0.5.13 software, using the CML2 baseline 2000 V2.05/World 1995 method from National Metal and Materials Technology Center (MTEC). Results were grouped into the six previously mentioned categories of impact: acidification, eutrophication, global warming, ozone layer depletion, human toxicity and photochemical oxidation.

\section{A. Carbonized Briquettes Made from Rain Tree Residues (RT100:CT0)}

$\mathrm{SO}_{2}$ emissions resulting from the use of diesel fuel for carbonizing rain tree residues were the main cause of acidification and photochemical oxidation, with the values of $59.70 \%$ and $96.01 \%$, respectively. The briquetting process caused eutrophication, global warming, ozone layer depletion and human toxicity with the values of $60.44 \%$, $73.64 \%, 98.87 \%$ and $97.02 \%$, respectively (Fig. 6). This was the result of using a high amount of electricity for the briquetting machine.

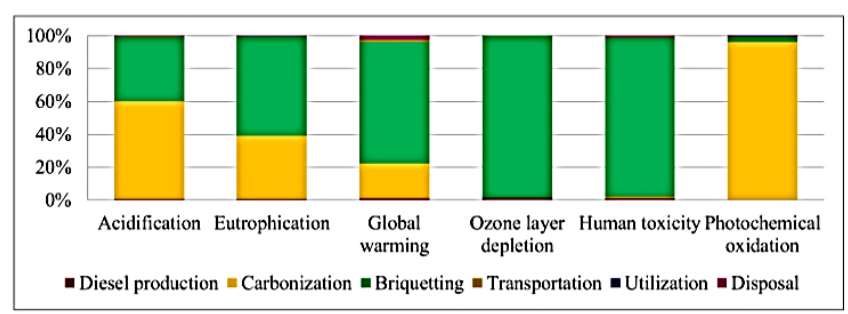

Fig. 6. Distribution of the environmental impact of carbonized briquettes made from $100 \%$ rain tree residues) RT100:CT0.

\section{B. Carbonized Briquettes Made from $75 \%$ Rain Tree} Residues and 25\% Coffee Grounds/tea Waste (RT75:CT25)

The main cause of six environmental impacts - acidification, eutrophication, ozone layer depletion, human toxicity and photochemical oxidation-was the briquetting process, with the values of $96.96 \%, 97.93 \%$, $94.80 \%, 98.82 \%, 97.94 \%$ and $87.74 \%$, respectively (Fig. 7). These impacts resulted from using a high amount of electricity for the briquetting machine.

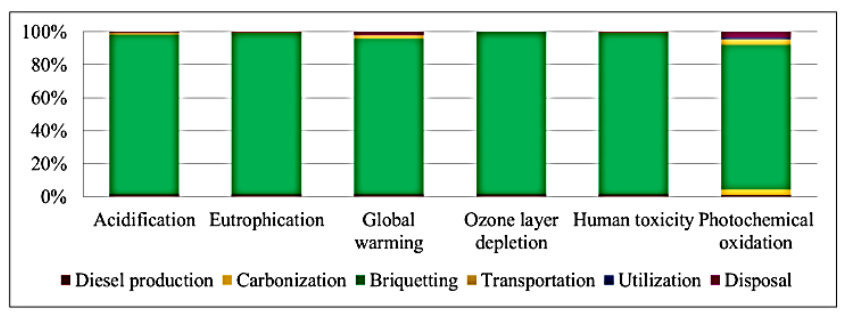

Fig. 7. Distribution of the environmental impact of carbonized briquettes made from $75 \%$ rain tree residues and $25 \%$ coffee grounds/tea waste (RT75:CT25)

\section{Carbonized Briquettes Made from 50\% Rain Tree Residues and 50\% Coffee Grounds/Tea Waste (RT50:CT50)}

The main cause of the six environmental impacts (acidification, eutrophication, ozone layer depletion, human toxicity and photochemical oxidation) was the briquetting process, with the values of $96.96 \%, 98.22 \%, 94.81 \%$, $98.82 \%, 98.11 \%$ and $88.03 \%$, respectively (Fig. 8). This resulted from the electricity consumption of the briquetting machine. 


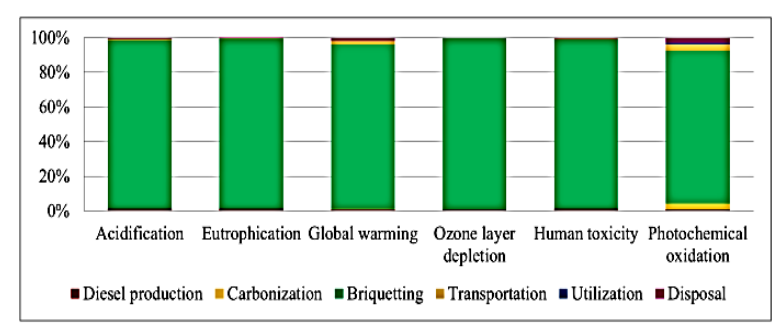

Fig. 8. Distribution of the environmental impact of carbonized briquettes made from 50\% rain tree residues and 50\% coffee grounds/tea waste (RT50:CT50).

\section{Carbonized Briquettes Made from $25 \%$ Rain Tree Residues and 75\% Coffee Grounds/Tea Waste (RT25:CT75)}

The values of the six impacts (acidification, eutrophication, ozone layer depletion, human toxicity and photochemical oxidation) were $90.72 \%, 95.66 \%, 81.11 \%, 98.82 \%, 94.69 \%$, and $88.03 \%$, respectively (Fig. 9). This was again due to the electricity usage of the briquetting machine.

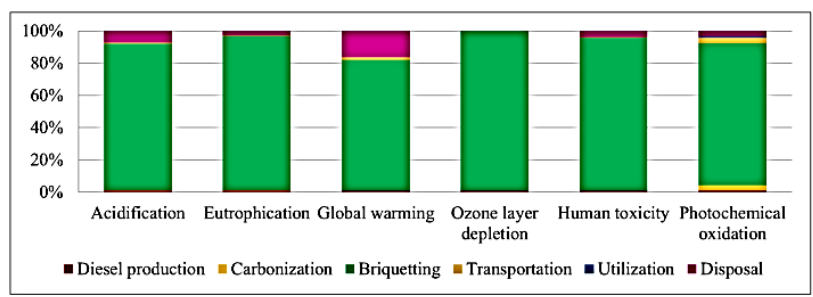

Fig. 9. Distribution of the environmental impact of carbonized briquettes made from $25 \%$ rain tree residues and $75 \%$ coffee grounds/tea waste (T25:CT75).

\section{E. Carbonized Briquettes Made from 100\% Coffee Grounds/Tea Waste (RT0:CT100)}

The main cause of eutrophication, global warming, ozone layer depletion and human toxicity was the high amount of electricity usage of the briquetting machine. The values of these impacts during the briquetting process were $61.99 \%$, $68.87 \%, 98.82 \%$ and $97.44 \%$, respectively. In the carbonization process, the environmental impacts were caused by the use of diesel fuel. This generated $\mathrm{SO}_{2}$ emissions that caused acidification and photochemical oxidation, with the values of $58.27 \%$ and $95.83 \%$, respectively (Fig. 10).

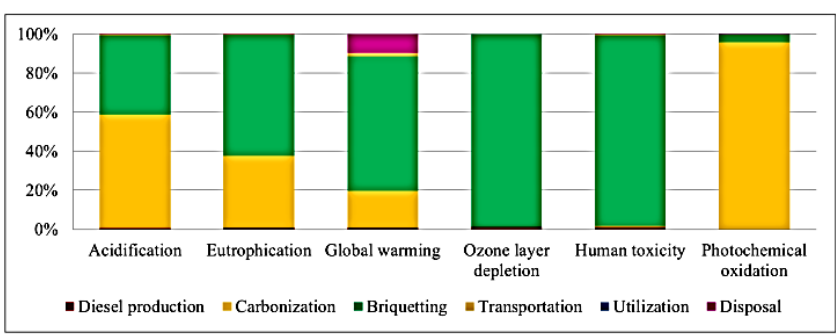

Fig. 10. Distribution of the environmental impact of carbonized briquettes made from 100\% coffee grounds/tea waste (RT0:CT100).

\section{F. Traditional Waste Management by Composting}

Composting released pollutants such as $\mathrm{NO}_{\mathrm{X}}$ and $\mathrm{NH}_{3}$. The composting process caused acidification, eutrophication and human toxicity with values of $99.95 \%, 100 \%$ and $99.86 \%$, respectively. The main cause of global warming and photochemical oxidation in this process was transportation of the compost from Chulalongkorn University to the consumer $(20 \mathrm{~km})$, both with values of $100 \%$ resulting from the combustion and pollutants emissions of diesel fuel (Fig. 11).

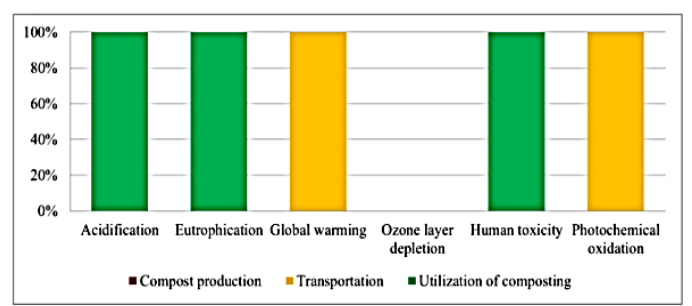

Fig. 11. Distribution of the environmental impact of traditional waste management of rain tree residues by composting.

\section{G. Traditional Waste Management by Landfill Disposal}

The main cause of six impacts-acidification, eutrophication, ozone layer depletion, human toxicity and photochemical oxidation - was transportation, with the value of $100 \%$ resulting from diesel fuel combustion and pollutants emissions resulting from transportation from Chulalongkorn University to the landfill (90 km) (Fig. 12).

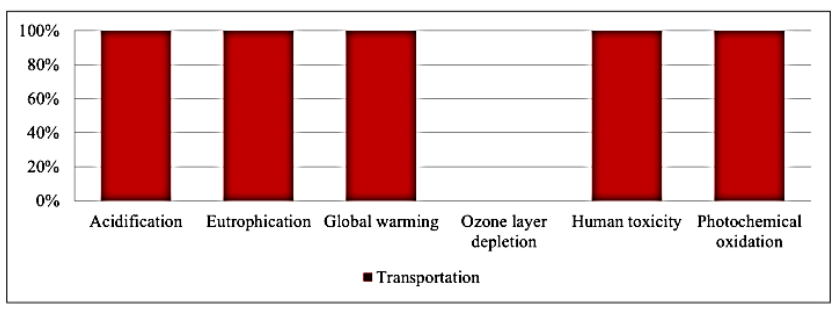

Fig. 12. Distribution of the environmental impact of traditional waste management of rain tree residues and coffee grounds/tea waste by landfill disposal.

\section{H. Comparison of the Environmental Impacts of Carbonized Briquettes and Traditional Waste Management}

The impacts from each process among the five different ratios of carbonized briquettes as well as traditional waste management processed were grouped into six categories, as shown in Fig. 13. Composting rain tree residues had the lowest impact on global warming, 0.02\%. Conversely, carbonized briquettes made from $100 \%$ coffee grounds/tea waste (RT0:CT100) had the highest impact on global warming resulting from the use of electricity and diesel fuel, a value of $21.57 \%$. In addition, the comparison of acidification and eutrophication among the five ratios of carbonized briquettes as well as traditional waste management processes showed that composting rain tree residues had the highest impact on acidification and eutrophication $(90.01 \%$ and $82.85 \%$, respectively), due to the pollutants $\mathrm{NO}_{\mathrm{X}}$ and $\mathrm{NH}_{3}$ that were released into the atmosphere. Thus, carbonized briquetting had less impact on acidification and eutrophication than composting. Furthermore, carbonized briquettes with the optimal ratio of RT50:CT50 impacted human toxicity with a value of $15.36 \%$ resulting from electricity and diesel fuel consumption. This was lower than landfill disposal, which had a value of $17.76 \%$. Fig. 13. presents the comparison of the environmental impacts among the five ratios of carbonized briquettes and traditional waste management processes. 


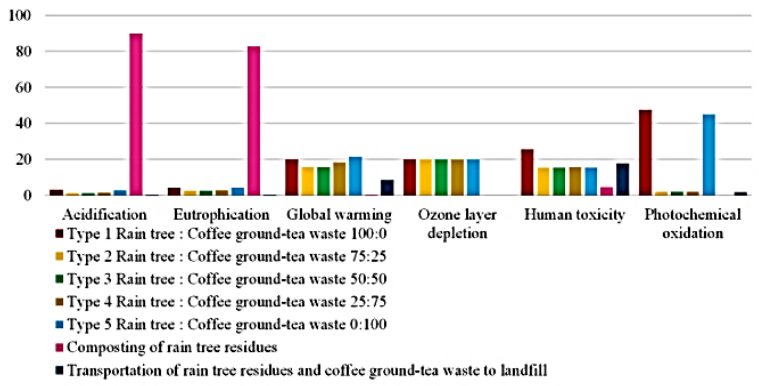

Fig. 13. Distribution of the environmental impacts among the five ratios of carbonized briquettes from rain tree residues and coffee grounds/tea waste and traditional waste management.

\section{Comparison with Other Researchers}

No previous research existed concerning the LCA over the cradle-to-grave life cycles of carbonized briquettes made from rain tree residues. However, some studies examined the LCA of briquettes or charcoal made with other residues, as shown in Table 1.

Wang et al. [16] investigated the environmental impact of the cradle-to-grave life cycle of cornstalk briquettes, a fuel in China. The results showed that briquettes made from cornstalks had global warming impacts of $11 \mathrm{~g} \mathrm{CO}_{2} \mathrm{eq} / \mathrm{MJ}$, which was higher than the global warming impacts of carbonized briquettes with the ratio of RT0:CT100. The highest impact of these briquettes was $0.0212 \mathrm{~kg} \mathrm{CO}_{2}$ eq or $7.02 \mathrm{~g} \mathrm{CO}_{2} \mathrm{eq} / \mathrm{MJ}$

Additionally, the results showed that cornstalk briquettes had the impact of $0.39 \mathrm{~g} \mathrm{SO}_{2} \mathrm{eq} / \mathrm{MJ}$ on human toxicity, which was higher than the human toxicity impacts from the carbonized briquettes with the ratio of RT25:CT75. The highest impact of the carbonized briquettes was $0.00603 \mathrm{~kg}$ $\mathrm{SO}_{2}$ eq or $0.052 \mathrm{~g} \mathrm{SO}_{2}$ eq/MJ. The impact from using electricity in the production of cornstalk briquettes was a major cause of global warming and human toxicity.

Adams, Shirley and McManus [17] published the environmental impacts of the cradle-to-grave life cycle of wood pallet production. The results showed that the wood pallet had the global warming impact value of $17.50 \mathrm{~g} \mathrm{CO} 2$ eq/MJ resulting from the grinding process. This was higher than the global warming impact of carbonized briquettes made from $100 \%$ coffee grounds/tea waste, which had the highest impact value of $7.02 \mathrm{~g} \mathrm{CO} 2 \mathrm{eq} / \mathrm{MJ}$.

TABLE I COMPARISON OF THE ENVIRONMENTAL IMPACTS AMONG THE FIVE RATIOS OF CARBONIZED BRIQUETTES AND TRADITIONAL WASTE MANAGEMENT PROCESSES WITH OTHER RESEARCH

\begin{tabular}{|c|c|c|c|c|c|}
\hline \multirow[t]{2}{*}{$\begin{array}{c}\text { Impact } \\
\text { categories }\end{array}$} & \multirow[t]{2}{*}{ Units } & \multicolumn{2}{|c|}{$\begin{array}{l}\text { Ratios of rain tree } \\
\text { residue and coffee } \\
\text { grounds/tea waste }\end{array}$} & \multirow{2}{*}{$\begin{array}{c}\text { Cornstalk } \\
\text { briquettes } \\
\text { (Wang et } \\
\text { al., 2017) }\end{array}$} & \multirow{2}{*}{$\begin{array}{c}\text { Wood } \\
\text { pallet } \\
\text { production } \\
\text { (Adams, } \\
\text { Shirley and } \\
\text { Mcmanus, } \\
2015 \text { ) }\end{array}$} \\
\hline & & $\begin{array}{l}\text { RT25: } \\
\text { CT75 }\end{array}$ & $\begin{array}{c}\text { RT0: } \\
\text { CT100 }\end{array}$ & & \\
\hline $\begin{array}{c}\text { Global } \\
\text { warming }\end{array}$ & $\mathrm{g} \mathrm{CO}_{2} \mathrm{eq}$ & $1.80 \mathrm{E}-02$ & 2.12E-02 & $1.1 \mathrm{E}+01$ & $1.75 \mathrm{E}+01$ \\
\hline $\begin{array}{l}\text { Human } \\
\text { toxicity }\end{array}$ & $\mathrm{g} \mathrm{SO}_{2}$ eq & $6.03 \mathrm{E}-03$ & $5.86 \mathrm{E}-03$ & $3.9 \mathrm{E}-01$ & - \\
\hline
\end{tabular}

Carbonized briquettes from rain tree residues and coffee grounds/tea waste were environmentally friendly products because they decreased waste to landfill and reduced needs for employing natural resources as raw materials. This study showed that using rain tree residues and coffee grounds/tea waste could be an alternative way to add value to biomass residues that are of good quality and are environmentally friendly. Carbonized briquettes could provide renewable energy for household cooking.

\section{CONCLUSIONS}

This study used the LCA to carry out an environmental evaluation of carbonized briquettes, from raw material acquisition to disposal. Environmental impacts of carbonized briquettes depended on carbonization and briquetting processes. Most of the emissions of these processes were attributed to exhausted pollutants from fuel used for carbonization and electricity used for the briquetting machine. The combustion of this fuel and electricity produced large amounts of air pollutants like carbon monoxide and nitrogen oxide.

Comparative results showed that carbonized briquette made from rain tree residues and coffee grounds/tea waste with the ratio of RT0:CT100 had a greater impact on global warming than the other four types of carbonized briquette and traditional disposal processes. This was due to the amount of electricity consumed by the briquetting machine, which led to a greater amount of atmospheric pollutants. However, this impact could be reduced by using different methods to replace electricity, such as a solar cell, or using other machines which require less power. Conversely, composting rain tree residues had the greatest impact on acidification and eutrophication due to the utilization of the compost for soil amendment, even though composting was an alternative way of adding value to the biomass residues.

Carbonized briquettes made from rain tree residues and coffee grounds/tea waste with the optimal ratio of RT50:CT50 had a greater impact on human toxicity than traditional disposal of these residues due to electricity consumption. Additionally, this ratio had less impact on global warming than the other ratios of carbonized briquettes, including RT100:CT0, RT25:CT75 and RT0:CT100.

Consequently, carbonized briquettes from rain tree residues and coffee grounds/tea waste could be an alternative way to reduce and to add value to biomass residues for use as raw materials for producing fuel products used in household cooking that are environmentally friendly.

\section{APPENDIX}

Appendixes, if needed, appear before the acknowledgment.

\section{CONFLICT OF INTEREST}

The authors declare no conflict of interest.

\section{AUTHOR CONTRIBUTIONS}

Nuta Supakata conducted, the research and wrote the paper; Nichakorn Chaisuwan and Nattakarn Kansai performed the experiments, analyzed and interpreted the data; Seksan Parpong contributed analysis tools and data; all authors had approved the final version. 


\section{ACKNOWLEDGMENT}

This project was supported by the Department of Environmental Science, Faculty of Science, Chulalongkorn University and was partially supported by the Research Program: Municipal Solid Waste and Hazardous Waste Management, the S\&T Postgraduate Education and Research Development Office, the Office of Higher Education Commission (HSM-PJ-CT-17-02). The authors gratefully acknowledge Prof. Dr. Tharapong Vitidsant (Chief of Fuels and Energy from Biomass Center), Mr. Sirichai Ratanawaraha (instructor and manager of Fuels and Energy from Biomass Center), Fuels and Energy from Biomass Center, Physical Resources Management, and the faculty of Engineering at Chulalongkorn University for providing mechanical equipment. The authors also would like to thank Dr. Sujitra Vassanadamrongdee (PI of Chula Zero Waste Project) for encouragement; METC for providing the software and database; Asst.Prof. Dr. Sarawut Srithongouthai, Asst.Prof. Dr. Vorapot Kanokantapong and Asst.Prof. Dr. Pantana Tor-ngern for their kindly suggestions.

\section{REFERENCES}

[1] (2004). Thai Community Product Standard. [Online]. Available: http://www.charcoal.snmcenter.com/charcoalthai/standard.php

[2] A. Gebresas, H. Asmelash, and T. Tesfay, "Briquetting of charcoal from sesame stalk," Journal of Energy, pp. 1-6, 2015.

[3] H. Haykiri-Acma, S. Yaman, and S. Kucukbayrak, "Production of biobriquettes from carbonized brown seaweed," Fuel Processing Technology, vol. 106, pp. 33-40, 2013.

[4] N. Kansai, N. Chaisuwan, and N. Supakata, "Carbonized briquettes as a tool for adding value to waste from rain tree )samanea saman( and coffee ground/tea waste," Engineering Journal, vol. 22, pp. 47-63, 2018.

[5] K. Tran, M. Alonso, L. Wang, and O. Skreiberg, "Simultaneously boosting the mass and fixed-carbon yields of charcoal from forest residues via atmospheric carbonization," Energy Procedia, vol. 105, pp. 787-792, 2017

[6] D. Pennise, K. Smith, J. Kithinji, M. Rezende, T. Raad, and J. Zhang, "Emissions of greenhouse gases and other airborne pollutants from charcoal making in Kenya and Brazil," Geophysical Research, vol. 106, pp. 143-155, 2001.

[7] M. Hojer, S. Ahlroth, K. Dreborg, T. Ekvall, G. Finnveden, and O. Hjelm, "Scenarios in selected tools for environmental systems analysis," Journal of Cleaner Production, vol. 16, pp. 1958-1970, 2008.

[8] S. Berg and E. Lindholm, "Energy use and environmental impacts of forest operations in Sweden," Journal of Cleaner Production, vol. 13, pp. 33-42, 2005.

[9] International Organization for Standardization, "ISO 14040: Environmental management-life cycle assessment-principals and framework. International organization for standardization," Geneva, Switzerland, 2006.

[10] C. Ji, K. Cheng, D. Nayak, and G. Pan, "Environmental and economic assessment of crop residues competitive utilization for biochar, briquette fuel and combined heat and power generation," Journal of Cleaner Production, vol. 192, pp. 916-923, 2018.

[11] H. Stichnothe and A. Azapagic, "Bioethanol from waste: Life cycle estimation of the greenhouse gas saving potential," Resources, Conservation and Recycling, vol. 53, pp. 624-630, 2009.

[12] J. Hu, T. Lei, Z. Wang, X. Yan, X. Shi, Z. Li, and X. He, "Economic, environmental and social assessment of briquette fuel from agricultural residues in China: A study on flat die briquetting using corn stalk," Energy, vol. 64, pp. 557-566, 2014

[13] P. Rousset, A. Caldeira-Pires, A. Sablowski, and T. Rodrigues, "LCA of eucalyptus wood charcoal briquettes," Journal of Cleaner Production, vol. 19, pp. 1647-1653, 2011.
[14] Intergovernmental Panel on Climate Change, "The 2006 IPCC guidelines for national greenhouse gas inventories," The National Greenhouse Gas Inventory Programme, IGES, Japan, 2006.

[15] European Economic Area, "EMEP/EEA air pollutant emission inventory guidebook 2016," European Environmental Agency (EEA), Luxembourg, 2016.

[16] Z. Wang, T. Lei, M. Yang, Z. Li, T. Qi, and X. Xin, "Life cycle environmental impacts of cornstalk briquette fuel in China," Applied Energy, vol. 192, pp. 83-94, 2017.

[17] P. Adams, J. Shirley, and M. McManus, "Comparative cradle-to-grave life cycle assessment of wood pellet production with torrefaction," Applied Energy, vol. 138, pp. 367-380, 2015.

Copyright $(9) 2020$ by the authors. This is an open access article distributed under the Creative Commons Attribution License which permits unrestricted use, distribution, and reproduction in any medium, provided the original work is properly cited (CC BY 4.0).

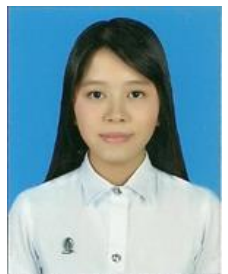

Nichakorn Chaisuwan got the B.S. in environmental science, Faculty of Science, Chulalongkorn University, Thailand. She is positive in Train Operations Planning and Development. She is inBangkok Expressway and Metro Public Company Limited. She published one paper: Kansai, N., Chaisuwan, N., and Supakata N. 2018. "Carbonized briquettes as a tool for adding value to waste from rain tree and coffee ground/tea waste".

Engineering Journal, 22 (6): 47-63.

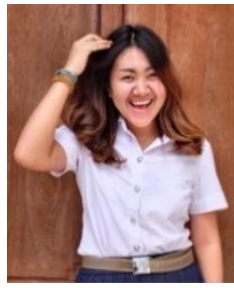

Nattakarn Kansai got the B.S. in environmental science, Faculty of Science, Chulalongkorn University, Thailand. She published one paper: Kansai, N., Chaisuwan, N., and Supakata N. 2018 "Carbonized briquettes as a tool for adding value to waste from rain tree and coffee ground/tea waste". Engineering Journal, 22 (6): 47-63.

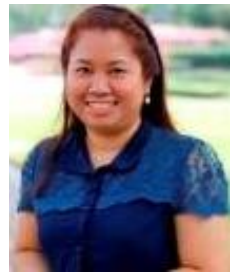

Nuta Supakata got the Ph.D. in Environmental Science, Kasetsart University, Thailand. She is an associate professor in the Department of Environmental Science, Faculty of Science, Faculty of Science, Chulalongkorn University, Bangkok, Thailand.

Her Publications: Hathaichanok Warnphen, Nuta Supakata, and Vorapot Kanokkantapong. The Reuse of Waste Glass as Aggregate Replacement for Producing Concrete Bricks as an Alternative for Waste Glass Management on Koh Sichang. Engineering Journal. 201923 (5): 43-58

Tapanee Sangpatch, Nuta Supakata, Vorapot Kanokkantapong, Bunjerd Jongsomjit. Fuel oil generated from the cogon grass-derived Al-Si (Imperata cylindrica (L.) Beauv) catalysed pyrolysis of waste plastics. Heliyon. 2019 5: $1-8$.

Punthama, C., Supakata, N., and Kanokkantapong, V. Characteristics of Concrete Bricks After Partially Substituting Portland Cement Type 1 with Cement and Seashell Waste and Partially Substituting Sand with Glass Waste. EnvironmentAsia. 201912 (1): 36 - 48.

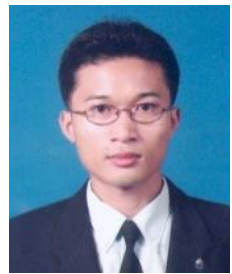

Seksan Papong got the Ph.D. in Environmental Informatics, Tokyo City University, Yokohama Campus, Japan. He is research specialist (life cycle asssessment) in National Metal and Materials Technology Center, Bangkok, Thailand

His Publications: Nuta Supakata, Pilaiporn Prachapadoong, Phathhanan Chaisupharut, Seksan

Papong, Characteristics and Environmental Assessment of Facing Bricks Produced from Dredged Sediments and Waste Glasses, Materials Science Forum, 1, 2017.

Seksan Papong, Chantima Rewlay-ngoen, Norihiro Itsubo, Pomthong Malakul. Environmental life cycle assessment and social impacts of bioethanol production in Thailand. Journal of Cleaner Production. 2017. 